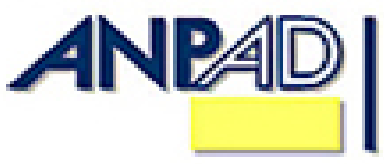

Available online at

http://www.anpad.org.br/bar

BAR, Rio de Janeiro, v. 12, n. 1, art. 4, pp. 63-87, Jan./Mar. 2015

http://dx.doi.org/10.1590/1807-7692bar2015140059

$((c)$ EY-No

\title{
The Effect of Simultaneous Sponsorship of Rival Football Teams
}

João Guilherme Barbosa de Amorim Universidade Federal do Rio de Janeiro - UFRJ/COPPEAD

Victor Manoel Cunha de Almeida Universidade Federal do Rio de Janeiro - UFRJ/COPPEAD

Received 13 October 2014; received in revised form 12 February 2015 (this paper has been with the authors for two revisions); accepted 13 February 2015; published online 17 March 2015. Editor's note. Valter Afonso Vieira served as Action Editor for this article. 


\begin{abstract}
The present study investigated the impact of team identification and team-sponsor fit on the sponsor's brand equity. The study's main theoretical references are (a) the Social Identity Theory (Tajfel \& Turner, 1979); (b) the Schema Theory (Singer, 1968) and (c) the Associative Network Theories (Collins \& Loftus, 1975), both about the functioning of the human memory; and (d) customer-based brand equity (Keller, 1993). Research was conducted in Porto Alegre, RS, a Brazilian city where rival football (soccer) teams Grêmio and Internacional share their main sponsors, Banrisul and Unimed, since 2001 and 2002, respectively, a rare context that was previously studied only once before (Davies, Veloutsou, \& Costa, 2006). The valid sample comprised 2,000 fans of both teams. The sample was non-probabilistic with equal gender and team quotas. Data analysis was performed using Exploratory Factor Analysis (EFA) and Confirmatory Factor Analysis (CFA); and the reliability, convergent, discriminant and nomological validity of the constructs were verified. To test the substantive hypotheses, Structural Equation Modeling (SEM) using the ADF technique was applied. The empirical results suggest that, in the studied context, the sponsor's brand equity is more influenced by teamsponsor fit than by team identification, which is different from a non-rivalry sponsorship context.
\end{abstract}

Key words: sports marketing; sports sponsorship; rival teams sponsorship; team identification; team-sponsor fit. 


\section{Introduction}

In the last decades, corporate sponsorship evolved from a merely philanthropic activity to a popular marketing tool (Cornwell, 2008). Sports sponsorship spending worldwide attained US\$ 35 billion in 2011, or $28.8 \%$ of the sports market, which also includes ticketing, broadcasting and merchandising rights. Sports sponsorship is expected to grow at an average rate of $5.3 \%$ per year worldwide until 2015, totaling US\$ 45 billion (PwC, 2011).

Worldwide, the highest paid football (soccer) sponsorship kit deals are (a) Manchester United and Chevrolet, US\$ 80 million, (b) Barcelona and Qatar Airways, US\$ 45 million, (c) Bayern Munich and Deutsche Telekom, US\$ 40 million, (d) Real Madrid and Fly Emirates, US\$ 39 million, and (e) Liverpool and Standard Chartered, US\$ 31 million (Arshad, 2014).

In Brazil, because of the recent happening of the FIFA World Cup in 2014 and the imminent holding of the Olympic Games in 2016, the amount spent in sport sponsorship, that reached a level of R \$ 3 billion in 2013 (approximately US\$ 6.75 billion at the 2013 average exchange rate of 2.25 Brazilian reais to 1 US dollar), should grow around $10 \%$ a year until 2016, with football (soccer) accounting for the lion's share (Lordello, 2013).

However, it is a well-known fact that most of the country's top 20 football (soccer) clubs lose money every year as well as being highly indebted. In 2013, the most indebted teams in Brazil were Flamengo, Botafogo and Vasco da Gama, with debts of $\mathrm{R} \$ 757.4, \mathrm{R} \$ 699.3$ and $\mathrm{R} \$ 518.4$ million, respectively. This situation reinforces the importance of funds derived from sports sponsorship, which have increased substantially in recent years and have become the clubs' third most important source of revenue after broadcasting rights and sale of athletes (Somoggi, 2014).

Companies face sport sponsorship as an important marketing communication tool (Walliser, 2003). In a sport-sponsorship deal, a company establishes a relationship with a team of a specific sport modality. Its most common form involves displaying the sponsoring company's logo on the sponsored team's jersey. However, other forms of imparting visibility to a brand are also used, such as exhibiting logos in stadiums and other sports facilities, on tickets, on team websites, on billboards near stadiums and during the broadcasting of the matches (Rines, 2000).

Many studies have been performed about sport sponsorship antecedents (Gwinner \& Eaton, 1999; Speed \& Thompson, 2000), team identification (Bennett, Ferreira, Lee, \& Polite, 2009; Gwinner $\&$ Swanson, 2003) and the brand objectives desired by sponsoring firms (Koo, Quarterman, \& Flynn, 2006; Roy \& Cornwell, 2003). More specifically, studies have shown that high level of team identification increase the sponsoring firm's brand equity (Wang, Cheng, Purwanto, \& Erimurti, 2011) and positively modify fans perceptions regarding event-sponsor fit (Gwinner \& Bennett, 2008). In addition, the perception of fit between the sponsor and the sponsored entity positively influences the sponsor's brand equity (Wang et al., 2011).

However, although sport sponsorship aims at strengthening the relationship between the team's fans and the sponsoring firm, the opposite can also happen in the case of fans of a rival team. One of the possible consequences of the extension of this rivalry is the rejection of potential consumers who support rival teams (Rines, 2000).

This negative reaction was observed in Brazil. A study showed that highly identified fans tend to demonstrate negative reactions regarding the sponsor of their team's rival, resulting in a negative effect in their purchase intentions of products of the sponsoring brand, even when the value proposition is recognizably good (Torres \& Andrade, 2012). It was also observed that the fans that identify the most with the team are the ones that are least likely to accept the sponsor when it is shared with its rival (Davies, Veloutsou, \& Costa, 2006). 
Walliser (2003) suggests that further studies in the field of corporate sponsorship compare the effects regarding different sport-sponsorship practices. The situation in which sponsors are shared by rivals is very rare and has hardly been explored by the literature. However, it constitutes precisely the context of the present study, whose aim is to investigate the impact of Team Identification and TeamSponsor Fit on Sponsor's Brand Equity. The study took place in Porto Alegre, a city in which the rival teams Grêmio and Internacional have been sharing their sponsors, Banrisul (Bank) and Unimed (Health-plan operator), for more than a decade.

\section{Theoretical Background and Hypotheses}

Cornwell and Maignan (1998) stated that one of the main gaps in the field of corporate sponsorship is the lack of underlying theory and conceptual foundations on which scholarly inquiry can be based. In order to contribute to fill this gap, we decided to organize this section presenting first the theoretical basis of the study, using the seminal studies of each theory, then the studies that applied each theory in the field of sport sponsorship. The Social Identity Theory and the theories that underpin studies of congruence, namely Schema Theory and Associative Network Theory, constitute the present study's theoretical framework.

\section{Social identity theory}

Social Identity Theory (SIT) deals with the importance of social groups as sources of individuals' social recognition, identification and insertion. Given that humans are social beings, belonging to certain groups - such as family, work colleagues and friends, among others - is part of each individual's life and psychological equilibrium (Tajfel \& Turner, 1979). According to SIT, individuals' self-concept is derived from both individual identity, which encompasses each person's particular characteristics, such as personality traits, and social or collective identity, which is composed of a series of identifications that each individual establishes with other people and groups, constituting shared characteristics shown in a social context (Tajfel \& Turner, 1979). Individuals perceive that they belong to an entity when they notice the similarities and differences between members of the social group they belong to and those that do not. Thus, the social identity of individuals is derived from the social categories they belong to, whether they are a demographically delimited group or, for example, the employees of an organization (Ashfort \& Mael, 1989). In the sports marketing context, a series of studies have been using SIT to explain different levels of fan identification with a specific sport (Gwinner \& Bennett, 2008), a sports event (Deitz, Myers, \& Stafford, 2012) or with a team (Davies et al., 2006; Gwinner, Larson, \& Swanson, 2009; Sutton, McDonald, Milne, \& Cimperman, 1997; Wann \& Branscombe, 1993).

\section{Fit theories}

Schema Theory suggests that access to information stored in memory is influenced by affinity or similarity, so that watching a running event sponsored by a footwear retailer seems to be appropriate to the consumer, thus making it easier to retrieve this sponsorship relation from memory (Deitz et al., 2012). A schema can be defined as a pre-existing supposition as to how the world is organized (Singer, 1968), or a cognitive structure which represents knowledge of a certain type of stimulus, thus considering that memory is a mixture of bits of previous knowledge that relate to each other (Gwinner \& Eaton, 1999). When new information becomes available, the individual tries to fit it in using the same patterns used in the past to interpret similar information. If this information cannot be satisfactorily framed, the individual finds another adequate scheme, adapting both the information and the schema (Axelrod, 1973).

Associative Network Theory (ANT) holds that memory consists of various bits of information called nodes, which are the formative concepts of the network of semantic relations where memorized 
information is stored. Each concept is a node formed by the set of properties of the related concepts or, considering the visual structure of a network, the nodes to which they are connected (Collins \& Loftus, 1975). The retrieval of stored information begins when a node is stimulated by a process known as activation, which is the initial impulse of the process of retrieving information contained in the network. Starting out from the node activated by the initial concept - for example a car - a search process, known as Spreading Activation, takes place traversing the network, node by node, identifying the concepts of wheel, tire, street, movement, gasoline, etc., until the related information is retrieved and the concept is reconstructed in the memory (Anderson, 1983).

In the sports-marketing context, a series of studies have used both theories to explain how the level of fit between a sponsor and the sponsored property can positively influence the results of a sport sponsorship agreement (Drengner, Jahn, \& Zanger, 2011). Considering that both theories seek to explain the same phenomenon, some studies are based in the ST (Deitz et al., 2012; Gwinner \& Eaton, 1999; Koo et al., 2006), while others are based in the ANT (Cornwell, Humphreys, Maguire, Weeks, \& Tellegen, 2006; Gwinner et al., 2009), showing convergent findings.

\section{Brand equity}

The literature presents two approaches of measuring brand equity: the finance-based approach which draws on methodologies used to value firms, usually linked to accounting aspects that are important in the case of, for example, mergers and acquisitions; and the consumer-based approach which has a strategic importance because, by understanding consumer behavior, firms can enhance their marketing efforts, using available resources more efficiently by making better decisions (Keller, 1993).

According to Aaker (1991), brand equity is a multidimensional concept that consists of four components: (a) perceived quality, with regard to the judgment of consumers in relation to the overall performance of the brand; (b) brand awareness, which is related to the familiarity of consumers with the brand; (c) brand associations, which can be understood as any mental link the consumer has with the brand; and (d) brand loyalty, or how much a brand can hold the attracted consumers.

Consumer-based brand equity (CBBE), which is the concept that underpins the present study, can be defined as "the differential effect of brand knowledge on consumer response to the marketing of the brand", thus constituting the incremental value perceived by the consumer due to the presence of the brand considering, as a basis of comparison, a same product category and identical marketing mix (Keller, 1993, p. 8).

In the sports-marketing context, Cornwell and Maignan (1998) suggested that the CBBE, as conceptualized by Keller (1993), is the ideal framework for the analysis of brand-related sponsorship effects, as it considers both brand image and brand awareness, and not only the latter.

The different definitions of brand equity do share a basic notion: brand equity is associated with the differential value conferred by the brand on a firm's product or service (Srivastava \& Shocker, 1991) or, in other words, the set of consumer perceptions, attitudes, knowledge and behaviors which result in an increase in utility and enable a brand to achieve a greater volume of sales or higher margins than it would without the brand name (Christodoulides \& Chernatony, 2010).

Brand equity can be measured directly or indirectly. The indirect approach seeks to measure brand equity through its component constructs, while the direct approach attempts to measure the differential impact of brand equity on consumers' responses to different elements of the marketing mix (Keller, 1993). Yoo and Donthu (2001) developed the Overall Brand Equity (OBE) scale, which uses the direct approach to measure brand equity from a consumer-based perspective using a single construct, and has been used by various studies found in the literature (Christodoulides, Chernatony, Furrer, Shiu, \& Abimbola, 2006; Jung \& Sung, 2008; Villarejo-Ramos \& Sánchez-Franco, 2005). 


\section{Team identification and consumer-based brand equity}

In this study, team identification refers to the connection of individuals with the team (Ashfort \& Mael, 1989). Fans who have strong identification with the teams have emotional connections with these sports organizations (Sutton et al., 1997), keeping them as a central part of their identity (Gwinner \& Swanson, 2003). From the perspective of the Social Identity Theory, a team's sponsor would be seen as a new member of the group, enjoying the positive outcomes of such status, since supporting this new group member would be a natural behavior of fans from the sponsored team (Fischer \& Wakefield, 1998).

Many studies relate the effects of team identification to the benefits obtained by sponsors. There is evidence in the literature that fans with high identification levels tend to show more positive reactions to sponsorship than fans that are less identified (Gwinner \& Swanson, 2003; Sutton et al., 1997). The results of this high level of identification include higher rates of brand recognition and satisfaction with the sponsor, high degree of support for the sponsoring firm (Gwinner \& Swanson, 2003), more frequent attendance to games (Fischer \& Wakefield, 1998), greater likelihood of buying a sponsor's products (Madrigal, 1995) and increase in the sponsoring firm's brand equity (Wang et al., 2011). This suggests that team identification contributes to differentiating the sponsoring firm's brand, thus increasing its brand equity, leading to the formulation of the first research hypothesis:

H1: Team identification has a positive impact on the sponsor's brand equity.

\section{Team identification and team-sponsor fit}

Social identification is the perceived unity or connection with a group of individuals (Ashfort \& Mael, 1989), which may be partially explained by the need to reinforce self-esteem, what occurs by belonging to a group that has qualities valued by the individual. Thus, individuals tend to reinforce their self-esteem by attributing positive aspects to the group they belong to and minimizing negative ones (Tajfel, 1982).

Considering that the sponsor is perceived as a member of the group, individuals tend to impart a positive bias to their opinions about the firm, reinforcing the perception of team-sponsor fit (Gwinner \& Swanson, 2003), especially when the benefits for the sponsored team are clearly perceived by the fans (Woisetschläger, Eiting, Haselhoff, \& Michaelis, 2010). This effect was also verified in the context of sports events, given that fans who identified with the sport positively modified their perceptions regarding event-sponsor fit (Gwinner \& Bennett, 2008). Thus, the second research hypothesis formulated was:

H2: Team identification has a positive impact on team-sponsor fit.

\section{Team-sponsor fit and customer-based brand equity}

The perception of fit between the sponsor and the sponsored entity, whether a sports event or team, can positively influence consumers' reactions and attitudes towards the sponsor (Roy \& Cornwell, 2003), the sponsor's brand image (Koo et al., 2006), it's level of brand recognition (Koo et al., 2006), brand recall (Johar \& Pham, 1999), brand attractiveness (Woisetschläger et al., 2010) and the firm's brand equity (Wang et al., 2011).

The rationale behind this effect is explained by the way human memory works. Both Schema Theory (Axelrod, 1973; Gwinner \& Eaton, 1999) and Associative Network Theory (Collins \& Loftus, 1975) affirm that fit is based on the mental relations established between sponsor and team, resulting in a mnemonic advantage for the sponsoring brand which is more entrenched in the minds of the most identified fans and thus more remembered and more present in their minds. 
Considering the definitions of brand equity (Aaker, 1991; Keller, 1993), it is known that brand awareness is one of its main constituents, therefore, this mnemonic advantage resultant from the perception of team-sponsor fit in a sports-sponsorship context contributes to the increase of the sponsor's brand equity. Thus, the third hypothesis formulated was:

H3: Team-sponsor fit has a positive impact on the sponsor's brand equity.

\section{Experience with the sponsors}

Studies about the mental processing of the sponsor-sponsored entity association indicate that individuals exhibit a positive bias towards sponsoring brands (Gwinner \& Eaton, 1999; Speed \& Thompson, 2000), and this has a series of positive consequences for these firms. However, considering that brand equity is formed by all direct or indirect contacts consumers have with firms (Ross, 2006; Villarejo-Ramos \& Sánchez-Franco, 2005), it can be influenced by communication messages or especially by consumers' previous experience with the firm at issue (Aaker, 1996), which constitutes the most important source of consumers' knowledge about a firm (Berry, 2000). Thus, the fan's experience with the sponsor attenuates the influence of team identification on the sponsor's brand equity. Therefore, the fourth research hypothesis formulated was:

H4: The fan's experience with the sponsor negatively moderates the relationship between team identification and the sponsor's brand equity.

Figure 1 presents the conceptual model and summarizes the study's substantive hypotheses.

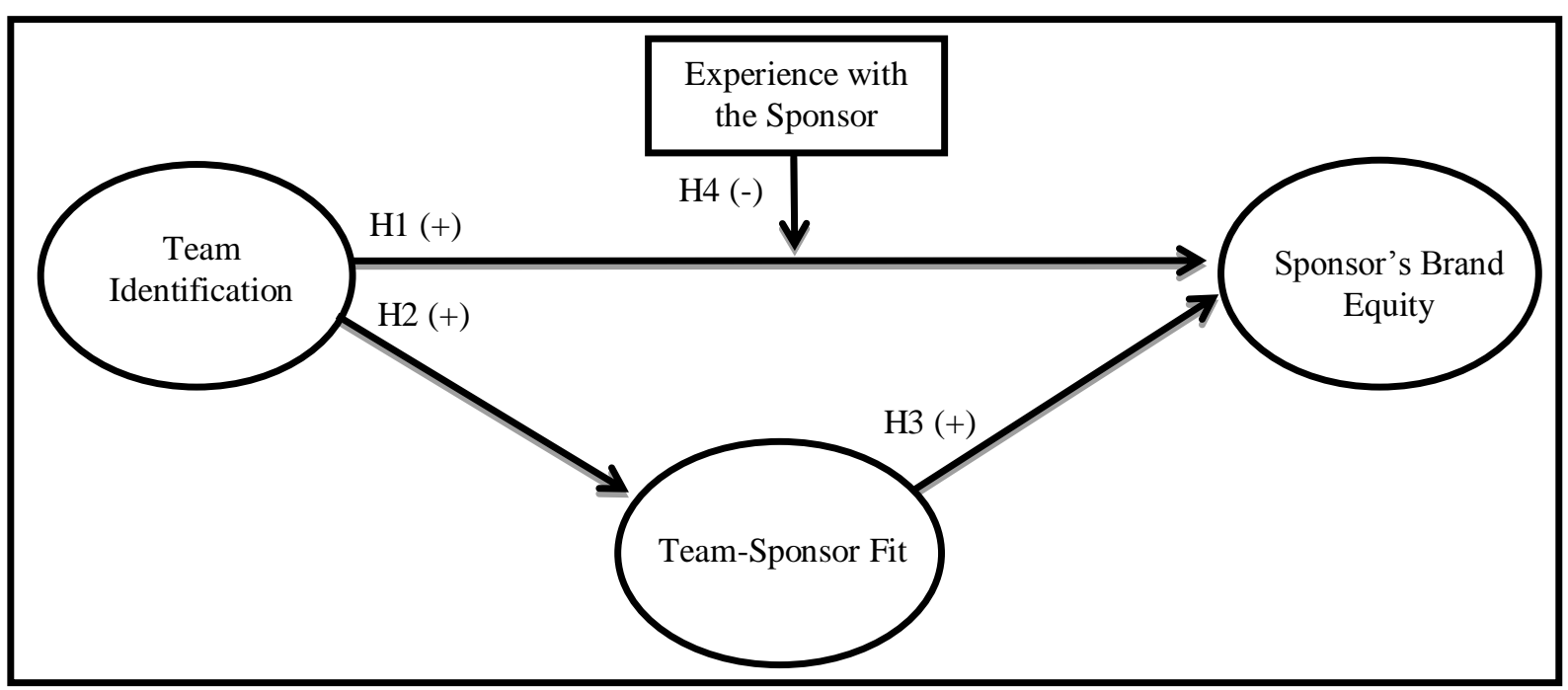

Figure 1. Conceptual Model

\section{Method}

The study is transversal and explanatory. We decided to delimit the study's scope by investigating the fans of Grêmio Foot-Ball Club Porto Alegrense (Grêmio) and Sport Club Internacional (Internacional), both from the Brazilian state of Rio Grande do Sul, because (a) they are located in the same city, Porto Alegre; (b) share four sponsors; (c) two of them, Banrisul and Unimed, since 2001 (Capelo, 2011) and 2002 (Turco, 2013) respectively. The joint sponsorship of Grêmio and International was, at the time of the data collection, the oldest joint sponsorship of rival football (soccer) teams in Brazil. 


\begin{abstract}
About the sponsors
Banrisul was created as the Banco do Estado do Rio Grande do Sul (BRGS) in 1928, with the initial aim of financing the state's rural producers. During the following decades, BRGS grew and incorporated a series of other local banks. In 2011, the bank had 1,259 service points and shareholder equity of $\mathrm{R} \$ 4.1$ billion. Although it has expanded into other regions of the country, 427 of its 441 branches are located in the state of Rio Grande do Sul (Banrisul, n.d.). Unimed Porto Alegre, founded in 1972, is a medical cooperative that operates in Porto Alegre's metropolitan area and the northern coastline of Rio Grande do Sul, covering 46 municipalities of the state. In 2013, Unimed Porto Alegre had 650,000 clients and 6,200 doctors, and had won the Top of Mind award in the city of Porto Alegre health-plan category for 18 consecutive years (Unimed do Brasil, 2013).
\end{abstract}

\title{
Measures
}

In order to operationalize the variables of the team identification construct, the research used Trail, Robinson, Dick and Gillentine's (2003) Points of Attachment Index scale, considering the revision proposed by Braunstein-Minkove, Zhang and Trail (2011), and which has already been translated to Portuguese and used in Brazil (Giacomini \& Almeida, 2013). For the team-sponsor fit construct the research used an adaptation of the Event-Sponsor Fit scale to the sports team context developed by Speed and Thompson (2000), which follows the literature's recommendation to use multiple item Likert scales to measure fit (Drengner et al., 2011). This scale was translated to Portuguese using the translation and back-translation process. Two pre-tests were conducted, using respondents of different economic and educational levels, professions and teams. The respondents were requested to be honest about any doubts or criticism that could arise about the questions of the questionnaire. Care was taken in order to carefully evaluate and interpret the gestures and facial expressions of the respondents. Because of the pre-tests we decided to change the word Fã (Fan) for Torcedor (Supporter), which is more popularly used in Brazil to refer to the relationship between a team and its fans. The sponsor's brand equity was operationalized using Yoo and Donthu's (2001) Overall Brand Equity scale, which has been widely used to measure firm brand equity around the world (Wang et al., 2011), and has already been translated to Portuguese and used in Brazil (Costa \& Almeida, 2012). Finally, the experience with the sponsor was operationalized as a categorical variable: respondents were asked if they were, at the time of the research, or had been, clients of each of the sponsoring companies. Therefore, the respondents were divided into two groups: experienced and inexperienced (no previous experience with the companies).

The questionnaire structure encompassed three sections, one for each of the scales used. The first section presented the team identification scale. The second section presented the brand equity scale for both sponsors. The third section presented the team-sponsor fit scale for both sponsors. In order to mitigate the eventual learning effect resultant of the double use of the brand equity and sponsor-fit scales in the same questionnaire, half of the questionnaires presented the items about Banrisul before the items about Unimed and half the other way around.

Table 1 details the original phrasing of the scales. The translated version of the scales used in the questionnaires can be seen in the Appendix. 
Table 1

Formulation of Items Used in the Questionnaire

\begin{tabular}{|c|c|c|}
\hline Scale & Item & Item Formulation \\
\hline \multirow{3}{*}{$\begin{array}{l}\text { Team Identification } \\
\text { (otid) }\end{array}$} & otid_1 & I consider myself to be a "real" fan of the (team) team. \\
\hline & otid_2 & I would experience a loss if I had to stop being a fan of the (team) team. \\
\hline & otid_3 & Being a fan of (team) is very important to me. \\
\hline \multirow{5}{*}{$\begin{array}{l}\text { Team-Banrisul Fit } \\
\text { (fit_b) }\end{array}$} & fit_b1 & There is a logical connection between the (team) and the (sponsor). \\
\hline & fit_b2 & The image of the (team) and the image of the (sponsor) are similar. \\
\hline & fit_b3 & The (sponsor) and the (team) fit together well. \\
\hline & fit_b4 & The (sponsor) and the (team) stand for similar things. \\
\hline & fit_b5 & It makes sense to me that (sponsor) sponsors this (team). \\
\hline \multirow{5}{*}{$\begin{array}{l}\text { Team-Unimed Fit } \\
\text { (fit_u) }\end{array}$} & fit_u1 & There is a logical connection between the (team) and the (sponsor). \\
\hline & fit_u2 & The image of the (team) and the image of the (sponsor) are similar. \\
\hline & fit_u3 & The (sponsor) and the (team) fit together well. \\
\hline & fit_u4 & The (sponsor) and the (team) stand for similar things. \\
\hline & fit_u5 & It makes sense to me that (sponsor) sponsors this (team). \\
\hline \multirow{4}{*}{$\begin{array}{l}\text { Banrisul Overall } \\
\text { Brand Equity } \\
\text { (obe_b) }\end{array}$} & obe_b1 & $\begin{array}{l}\text { It makes sense to buy (sponsor) instead of any other brand, even if they are } \\
\text { the same. }\end{array}$ \\
\hline & obe_b2 & $\begin{array}{l}\text { Even if another brand has the same features as (sponsor), I would prefer to } \\
\text { buy (sponsor). }\end{array}$ \\
\hline & obe_b3 & If there is another brand as good as (sponsor), I prefer to buy (sponsor). \\
\hline & obe_b4 & $\begin{array}{l}\text { If another brand is not different from (sponsor) in any way, it seems smarter } \\
\text { to purchase (sponsor). }\end{array}$ \\
\hline \multirow{4}{*}{$\begin{array}{l}\text { Unimed Overall } \\
\text { Brand Equity } \\
\text { (obe_u) }\end{array}$} & obe_u1 & $\begin{array}{l}\text { It makes sense to buy (sponsor) instead of any other brand, even if they are } \\
\text { the same. }\end{array}$ \\
\hline & obe_u2 & $\begin{array}{l}\text { Even if another brand has the same features as (sponsor), I would prefer to } \\
\text { buy (sponsor). }\end{array}$ \\
\hline & obe_u3 & If there is another brand as good as (sponsor), I prefer to buy (sponsor). \\
\hline & obe_u4 & $\begin{array}{l}\text { If another brand is not different from (sponsor) in any way, it seems smarter } \\
\text { to purchase (sponsor). }\end{array}$ \\
\hline
\end{tabular}

\section{Sample and data collection}

Data was collected using a non-probabilistic sampling technique during a period of 23 consecutive days (between April 13 and May 5, 2013), with equal team and gender quotas. After pretesting the questionnaire, the research interviewed 2,116 fans. From the 2,116 interviews performed, 116 were discarded due to incomplete answering, resulting in 2,000 valid observations.

The fans were interviewed by a team of trained interviewers, using assisted collection. Interviewees were approached in crowded public places such as squares, streets, bus stops and openair commercial centers. We decided not to perform interviews near football (soccer) stadiums or on match days to avoid the bias of interviewing many fans with high team-identification levels. The 
research followed Wann's (2002) suggestion to only interview fans who declared that they were supporters of one of the teams and were able to spontaneously recall (unaided recall) the name of one the sponsors of the two clubs investigated. The respondents that qualified as fans by mentioning only one of the studied sponsors were then presented to the other sponsor (aided recall), so that they could answer the following items of the questionnaire.

\section{Exploratory factor analysis}

Exploratory Factor Analysis (EFA) was performed using SPSS version 18. Construct reliability was assessed by verifying Cronbach's Alfa and the corrected item-total correlation coefficients of the scales. The preliminary assessment of construct validity was performed by analyzing the Correlation Matrix, examining the correlation between variables of the same construct (convergent validity) and the correlation between variables of different constructs (discriminant validity). Indicators were assessed considering expected minimum limits, in accordance with Hair, Black, Babin, Anderson, and Tatham (2006). Five factors were extracted using the Principal Axis Factoring method with Direct Oblimin rotation and the EFA adequacy was measured using the KMO test (.891) and MSA. The Total Variance Explained was $71.1 \%$. There were no overlap among factors or cross loadings, that is, the items of each one of the scales formed one specific factor, implying that there were no evidences of the common method bias.

\section{Confirmatory factor analysis}

Confirmatory Factor Analysis (CFA) was undertaken using AMOS version 17. Firstly, the multi-normality of variables was tested using kurtosis indicators for each item and multivariate kurtosis. As it was not possible to ensure data multi-normality, the research decided to perform the CFA using the Asymptotic Distribution Free (ADF) technique, which does not impose the premise of normal data distribution (Kline, 2005). The measurement models of each scale were assessed using the following quality of fit indicators: $\chi^{2} ; \chi^{2} / \mathrm{df}$; GFI; RMSEA; PCLOSE; and CFI. Construct reliability was assessed by using the Construct Reliability (CR) indicator. Convergent validity was verified through the standardized regression coefficients of each construct and the analysis of Average Variance Extracted (AVE). Discriminant validity was assessed by analyzing the correlation between constructs and performing the test proposed by Fornell and Larcker (1981), who suggest taking the squared correlation between constructs and comparing it with each construct's AVE. Nomological validity was assessed through the significance and sign of relations.

\section{Mediation effect testing}

In order to verify the mediation effect of team-sponsor fit, a mediation test was conducted using Baron and Kenny's (1986) causal steps approach, which is well suited for the assessment of a single intervening variable (Holbert \& Stephenson, 2003), especially when the sample size is larger than 500 (Frazier, Tix, \& Barron, 2004). The significance of the mediation was tested using Sobel's approach (Sobel, 1982).

\section{Substantive hypotheses testing}

The study's substantive hypotheses testing was undertaken using Structural Equation Modeling (SEM), a technique which combines a series of separate multiple regression equations, albeit simultaneously, and permits the estimation of dependency relations, latent variables and the measurement errors in these variables. To test these hypotheses, the research assessed the paths hypothesized in the theoretical framework (see Figure 1). To test the hypothesis of the moderating effect of the experience with the sponsors, the research used the Multigroup Analysis technique through cross-validation of the invariance of the models for distinct groups, examining the significance of the variation of the $\chi^{2}$ indicator between models. 


\section{Results}

The age of the participants ranged from 18 to 92 years old, with an average of 35 and median of 31. Half of the sample was composed of Grêmio fans $(\mathrm{N}=1,000)$ and half of Internacional fans $(\mathrm{N}=1,000)$ with equal quotas for men and women (See Table 2).

Table 2

Sample Profile

\begin{tabular}{|c|c|c|c|c|c|c|c|c|c|c|}
\hline & & & \multicolumn{4}{|c|}{ Gender } & \multicolumn{4}{|c|}{ Age Group } \\
\hline & \multicolumn{2}{|c|}{ General } & \multicolumn{2}{|c|}{ Female } & \multicolumn{2}{|c|}{ Male } & \multicolumn{2}{|c|}{ Up to 30 years } & \multicolumn{2}{|c|}{$>30$ years } \\
\hline & $\mathrm{N}$ & $\%$ & $\mathrm{~N}$ & $\%$ & $\mathrm{~N}$ & $\%$ & $\mathrm{~N}$ & $\%$ & $\mathrm{~N}$ & $\%$ \\
\hline Grêmio & 1000 & $50 \%$ & 500 & $50 \%$ & 500 & $50 \%$ & 452 & $47.3 \%$ & 548 & $52.5 \%$ \\
\hline Internacional & 1000 & $50 \%$ & 500 & $50 \%$ & 500 & $50 \%$ & 504 & $52.7 \%$ & 496 & $47.5 \%$ \\
\hline Total & 2000 & $100 \%$ & 1000 & $50 \%$ & 1000 & $50 \%$ & 956 & $47.8 \%$ & 1044 & $52.2 \%$ \\
\hline
\end{tabular}

The preliminary assessment of the reliability and validity indicators undertaken in the EFA showed good indicators, suggesting good adequacy of the scales (see Table 3). Good indicators were verified: the Cronbach's alphas $(\alpha)$ were higher than .80 ; the corrected item-total correlation indicators were above the expected lower limit of .50; the correlation coefficients between items of the same construct ranged in general from .50 to .90 . The correlation coefficients between items of a construct and items of other constructs suggest discriminant validity of all items, given that none had values above the upper limit (.50).

The definitive assessment of the reliability and validity indicators performed in the CFA confirmed the good results obtained in the EFA (see Table 4). The research verified that the CR reliability indicators all had values above .80 . The items had high-standardized coefficients in the expected constructs (over .60). The AVE indicators, in bold type in the lower part of Table 4, were above the expected lower limit of .50 for all scales, suggesting good discriminant validity. The verification of discriminant validity was also undertaken using the test proposed by Fornell and Larcker (1981), comparing the squared correlation between the items and the AVE. The research verified that in all cases the AVE indicators were higher than the squared correlation.

The Structural Model was specified considering the three constructs of the conceptual framework, each one with between three and five measurement items. The indicators attest goodness of fit of both structural models. In the case of the Banrisul: $\chi^{2} / \mathrm{df}$ of 3.6 was slightly above the expected upper limit of 3, but below the acceptable limit f 5; GFI of .974 and CFI of .960, both above the expected limit of 0.9; RMSEA of .036, below the expected limit of 0.05 and PCLOSE of 1.000, above the expected limit of 0.5 . The indicators of the Unimed's structural model were the following: $\chi^{2} / \mathrm{df}$ of 2.8; GFI of .978 and CFI of .969; RMSEA of .030 and PCLOSE of 1.000. 
Table 3

\section{Correlation Matrix}

\begin{tabular}{|c|c|c|c|c|c|c|c|c|c|c|c|c|c|c|c|c|c|c|c|c|c|c|c|}
\hline \multirow[b]{3}{*}{ Item } & \multirow[b]{3}{*}{ Mean } & \multirow[b]{3}{*}{ S.D. } & \multirow{2}{*}{\multicolumn{3}{|c|}{$\begin{array}{c}\text { Identification } \\
\alpha=.834\end{array}$}} & \multicolumn{4}{|c|}{ Banrisul Brand Equity } & \multicolumn{4}{|c|}{ Unimed Brand Equity } & \multicolumn{5}{|c|}{ Team-Banrisul Fit } & \multicolumn{5}{|c|}{ Team-Unimed Fit } \\
\hline & & & & & & \multicolumn{4}{|c|}{$\alpha=.951$} & \multicolumn{4}{|c|}{$\alpha=.950$} & \multicolumn{5}{|c|}{$\alpha=.888$} & \multicolumn{5}{|c|}{$\alpha=.892$} \\
\hline & & & 1 & 2 & 3 & 4 & 5 & 6 & 7 & 8 & 9 & 10 & 11 & 12 & 13 & 14 & 15 & 16 & 17 & 18 & 19 & 20 & 21 \\
\hline otid_1 & 5.6 & 1.56 & 1.00 & & & & & & & & & & & & & & & & & & & & \\
\hline otid_2 & 4.3 & 2.19 & .56 & 1.00 & & & & & & & & & & & & & & & & & & & \\
\hline otid_3 & 5.0 & 1.82 & .69 & .68 & 1.00 & & & & & & & & & & & & & & & & & & \\
\hline obe_B1 & 4.3 & 1.86 & .11 & .15 & .18 & 1.00 & & & & & & & & & & & & & & & & & \\
\hline obe_B2 & 4.0 & 1.96 & .08 & .17 & .18 & .83 & 1.00 & & & & & & & & & & & & & & & & \\
\hline obe_B3 & 3.9 & 1.98 & .09 & .18 & .19 & .80 & .89 & 1.00 & & & & & & & & & & & & & & & \\
\hline obe_B4 & 4.0 & 2.04 & .06 & .13 & .16 & .77 & .83 & .83 & 1.00 & & & & & & & & & & & & & & \\
\hline obe_U1 & 4.5 & 1.8 & .15 & .15 & .19 & .24 & .21 & .22 & .19 & 1.00 & & & & & & & & & & & & & \\
\hline obe_U2 & 4.4 & 1.86 & .13 & .13 & .18 & .24 & .22 & .22 & .21 & .85 & 1.00 & & & & & & & & & & & & \\
\hline obe_U3 & 4.2 & 1.91 & .13 & .15 & .19 & .28 & .26 & .29 & .26 & .79 & .86 & 1.00 & & & & & & & & & & & \\
\hline obe_U4 & 4.4 & 1.91 & .12 & .15 & .19 & .28 & .25 & .27 & .31 & .76 & .81 & .82 & 1.00 & & & & & & & & & & \\
\hline fit_B1 & 5.0 & 1.66 & .16 & .12 & .17 & .30 & .30 & .30 & .30 & .14 & .15 & .17 & .19 & 1.00 & & & & & & & & & \\
\hline fit_B2 & 4.5 & 1.8 & .11 & .12 & .15 & .41 & .41 & .41 & .41 & .17 & .18 & .20 & .21 & .61 & 1.00 & & & & & & & & \\
\hline fit_B3 & 4.6 & 1.8 & .13 & .12 & .16 & .44 & .43 & .44 & .43 & .19 & .19 & .21 & .24 & .57 & .80 & 1.00 & & & & & & & \\
\hline fit_B4 & 4.2 & 1.79 & .06 & .13 & .13 & .38 & .41 & .41 & .41 & .15 & .17 & .20 & .21 & .58 & .70 & .68 & 1.00 & & & & & & \\
\hline fit_B5 & 5.3 & 1.78 & .13 & .10 & .15 & .34 & .34 & .33 & .33 & .15 & .16 & .16 & .17 & $.46^{\mathrm{a}}$ & .56 & .63 & .50 & 1.00 & & & & & \\
\hline
\end{tabular}

Continues 
Table 3 (continued)

\begin{tabular}{|c|c|c|c|c|c|c|c|c|c|c|c|c|c|c|c|c|c|c|c|c|c|c|c|}
\hline \multirow[b]{3}{*}{ Item } & \multirow[b]{3}{*}{ Mean } & \multirow[b]{3}{*}{ S.D. } & \multirow{2}{*}{\multicolumn{3}{|c|}{$\begin{array}{c}\text { Identification } \\
\alpha=.834\end{array}$}} & \multicolumn{4}{|c|}{ Banrisul Brand Equity } & \multicolumn{4}{|c|}{ Unimed Brand Equity } & \multicolumn{5}{|c|}{ Team-Banrisul Fit } & \multicolumn{5}{|c|}{ Team-Unimed Fit } \\
\hline & & & & & & \multicolumn{4}{|c|}{$\alpha=.951$} & \multicolumn{4}{|c|}{$\alpha=.950$} & \multicolumn{5}{|c|}{$\alpha=.888$} & \multicolumn{5}{|c|}{$\alpha=.892$} \\
\hline & & & 1 & 2 & 3 & 4 & 5 & 6 & 7 & 8 & 9 & 10 & 11 & 12 & 13 & 14 & 15 & 16 & 17 & 18 & 19 & 20 & 21 \\
\hline fit_U1 & 4.5 & 1.75 & .09 & .10 & .15 & .18 & .17 & .17 & .17 & .29 & .32 & .31 & .32 & .47 & .28 & .28 & .28 & .22 & 1.00 & & & & \\
\hline fit_U2 & 4.1 & 1.75 & .08 & .15 & .17 & .23 & .24 & .27 & .25 & .38 & .41 & .42 & .42 & .34 & .43 & .38 & .39 & .26 & .60 & 1.00 & & & \\
\hline fit_U3 & 4.3 & 1.77 & .11 & .15 & .20 & .24 & .24 & .24 & .23 & .42 & .44 & .43 & .43 & .35 & .40 & .43 & .37 & .32 & .58 & .80 & 1.00 & & \\
\hline fit_U4 & 3.7 & 1.73 & .06 & .18 & .15 & .24 & .27 & .29 & .25 & .37 & .40 & .42 & .40 & .30 & .34 & .33 & .40 & .23 & .59 & .72 & .67 & 1.00 & \\
\hline fit_U5 & 5.0 & 1.79 & .12 & .13 & .16 & .20 & .19 & .19 & .18 & .34 & .36 & .36 & .37 & .30 & .33 & .34 & .30 & .46 & $.46^{\mathrm{a}}$ & .57 & .63 & .50 & 1.00 \\
\hline \multicolumn{3}{|c|}{ Item-total correlation } & .69 & .67 & .78 & .84 & .92 & .90 & .86 & .86 & .91 & .89 & .85 & .67 & .81 & .82 & .73 & .63 & .67 & .82 & .82 & .74 & .63 \\
\hline \multicolumn{3}{|c|}{$\alpha$ if item excluded } & .80 & .83 & .69 & .95 & .92 & .93 & .94 & .94 & .92 & .93 & .94 & .88 & .85 & .84 & .86 & .89 & .88 & .85 & .85 & .87 & .89 \\
\hline
\end{tabular}

Note. ${ }^{a}$ Below the expected limit of 0.5 . 
Table 4

Reliability and Validity Indicators

\begin{tabular}{|c|c|c|c|c|c|c|}
\hline \multirow[b]{3}{*}{ Item } & \multicolumn{3}{|c|}{ Banrisul } & \multicolumn{3}{|c|}{ Unimed } \\
\hline & $\begin{array}{l}\text { Identificatio } \\
\mathrm{n} \text { (otid) }\end{array}$ & Fit (fit_b) & $\begin{array}{l}\text { Brand Equity } \\
\text { (obe_b) }\end{array}$ & $\begin{array}{l}\text { Identification } \\
\text { (otid) }\end{array}$ & Fit (fit_u) & $\begin{array}{l}\text { Brand Equity } \\
\text { (obe_u) }\end{array}$ \\
\hline & $\mathrm{CR}=.857$ & $\mathrm{CR}=.894$ & $\mathrm{CR}=.959$ & $\mathrm{CR}=.854$ & $\mathrm{CR}=.901$ & $\mathrm{CR}=.960$ \\
\hline otid_1 & .782 & & & .768 & & \\
\hline otid_2 & .732 & & & .722 & & \\
\hline otid_3 & .927 & & & .939 & & \\
\hline fit_1 & & .693 & & & .675 & \\
\hline fit_2 & & .886 & & & .895 & \\
\hline fit_3 & & .908 & & & .921 & \\
\hline fit_4 & & .745 & & & .791 & \\
\hline fit_5 & & .716 & & & .718 & \\
\hline obe_1 & & & .883 & & & .901 \\
\hline obe_2 & & & .963 & & & .962 \\
\hline obe_3 & & & .940 & & & .931 \\
\hline obe_4 & & & .906 & & & .905 \\
\hline otid & .669 & .203 & .232 & .664 & .217 & .236 \\
\hline fit & .041 & .631 & .519 & .047 & .649 & .517 \\
\hline obe & .054 & .269 & .853 & .056 & .267 & .856 \\
\hline
\end{tabular}

Note. Values on the diagonal refer to average variance extracted; values above the diagonal refer to correlation; values below the diagonal refer to squared correlation.

In order to verify the stability of the factorial structure, the sample was segmented using the criteria of gender, age-group and fan's team. The results were equally satisfactory. The factorial structure was found to be stable, attesting the conceptual model's goodness of fit. The model was able to explain 29\% and 28\% of the variance of Banrisul and Unimed's brand equity, respectively, and only $4 \%$ to $5 \%$ of the variance team-sponsor fit, also respectively (see Figure 2). 


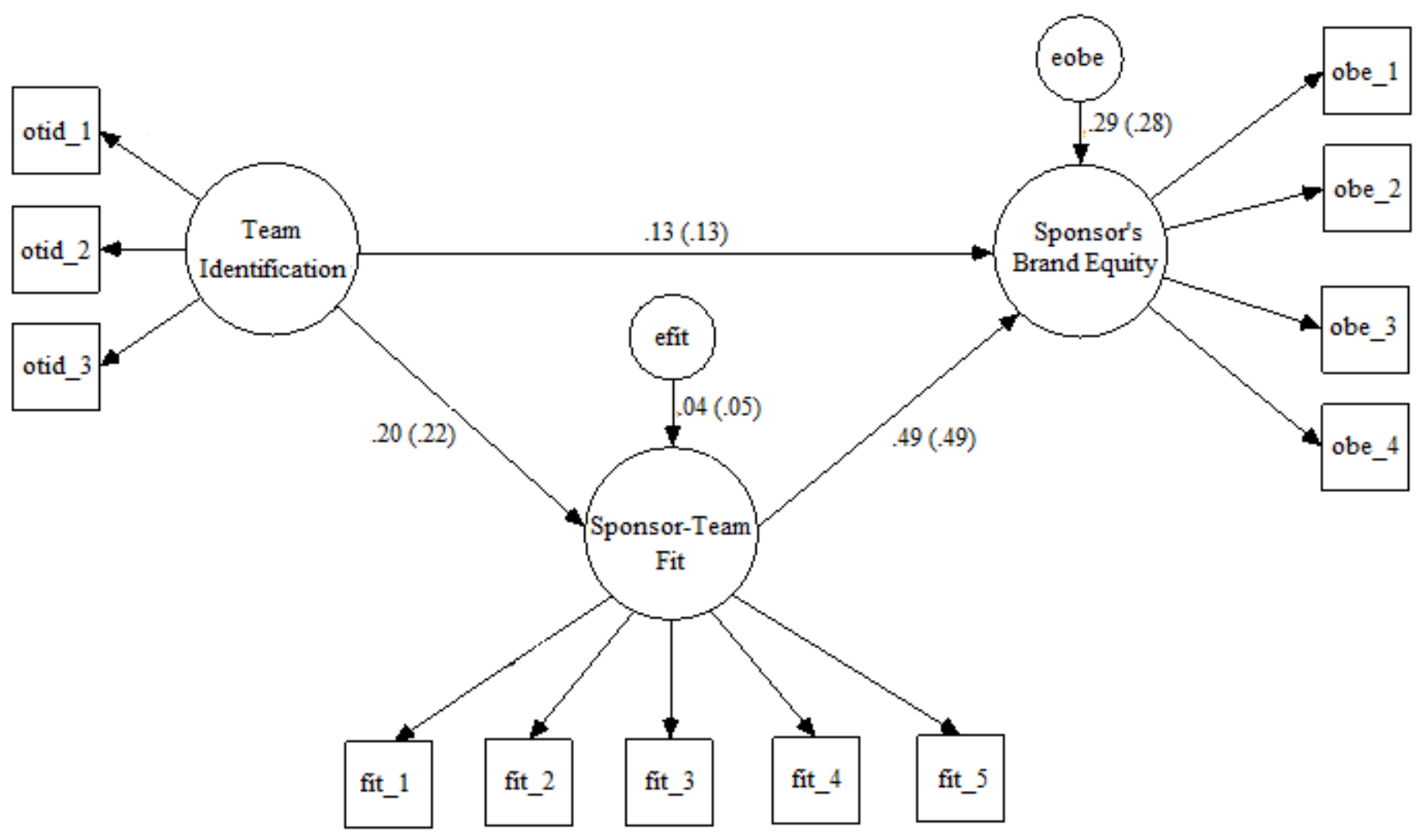

Figure 2. Structural Model

In the figure, the standardized coefficients outside brackets refer to the Banrisul's results, while the coefficients within brackets refer to Unimed's. 
The substantive hypotheses tests were undertaken using Structural Equations Modeling for hypotheses H1, H2 and H3, and Multigroup Analysis for hypothesis H4. It was possible to offer statistical support to substantive hypotheses $\mathrm{H} 1, \mathrm{H} 2$ and $\mathrm{H} 3$, for both sponsors, considering the critical p-value level of .01. However, the standardized coefficient, which indicates the strength of the relationship, suggests that only team-sponsor fit showed relevant influence on the sponsor's brand equity. Therefore, hypotheses $\mathrm{H} 1$ and $\mathrm{H} 2$ were only partially supported (see Table 5).

Table 5

Results of Hypotheses H1, $\mathrm{H} 2$ and $\mathrm{H3}$

\begin{tabular}{ccccccc}
\hline Hypothesis & Sponsor & Path & $\begin{array}{c}\text { Standardized } \\
\text { Coefficients }\end{array}$ & C.R. & p-value & Result \\
\hline H1 & & OBE $<$-OTID & .132 & 5.771 & $* * *$ & Part. Supported \\
H2 & Banrisul & FIT $<$-OTID & .203 & 7.823 & $* * *$ & Part. Supported \\
H3 & & OBE $<$-FIT & .492 & 19.116 & $* * *$ & Supported \\
\hline H1 & & OBE $<$-OTID & .130 & 5.629 & $* * *$ & Part. Supported \\
H2 & Unimed & FIT $<-$ OTID & .217 & 8.549 & $* * *$ & Part. Supported \\
H3 & & OBE <-FIT & .489 & 18.805 & $* * *$ & Supported \\
\hline
\end{tabular}

Note. $* * *$ Significant at the .001 level.

We then investigated the existence of the moderating effect of the experience with the sponsors. In order to do this analysis, it was necessary to verify the Model's Factorial Structural Equivalence, which was supported (see Table 6).

Table 6

\section{Results of Factorial Equivalence Tests}

\begin{tabular}{clccccccc}
\hline \multirow{2}{*}{ Sponsor } & \multirow{2}{*}{ Model } & \multicolumn{7}{c}{ Model Fit Indicators } \\
\cline { 3 - 8 } & & $\chi^{2}$ & $\mathrm{P}$ & $\chi^{2} / \mathrm{df}$ & GFI & CFI & RMSEA & PCLOSE \\
\hline \multirow{3}{*}{ Banrisul } & Experienced & 138.824 & $* * *$ & 2.722 & .963 & .952 & .039 & .991 \\
& Inexperienced & 105.651 & $* * *$ & 2.072 & .970 & .963 & .035 & .995 \\
\cline { 2 - 8 } & Factorial Equivalence & 244.475 & $* * *$ & 2.397 & .967 & .957 & .026 & 1.000 \\
\hline \multirow{3}{*}{ Unimed } & Experienced & 110.316 & $* * *$ & 2.163 & .960 & .946 & .038 & .974 \\
& Inexperienced & 92.329 & $* * *$ & 1.810 & .978 & .979 & .026 & 1.000 \\
\cline { 2 - 8 } & Factorial Equivalence & 202.658 & $* * *$ & 1.987 & .971 & .967 & .022 & 1.000 \\
\hline
\end{tabular}

Note. *** Significant at the .001 level.

The results of all paired comparisons between groups of models were then examined, verifying whether some of the paths reveal significant differences between delimited groups (CR for difference between parameters higher than the critical value of |1.96|). It was found that experience only had a moderating effect in the case of Banrisul (see Table 7). Although the moderating effect was not statistically significant in the case of Unimed, the results are aligned, given that in both cases the group without experience with the sponsor showed a higher non-standardized coefficient. 
Table 7

Results of the Moderation Tests

\begin{tabular}{|c|c|c|c|c|c|c|c|c|c|c|c|}
\hline \multirow{3}{*}{ Sponsor } & \multirow{3}{*}{ Нyp. } & \multirow{3}{*}{ Path } & \multicolumn{4}{|c|}{ Experienced } & \multicolumn{4}{|c|}{ Inexperienced } & \multirow{3}{*}{$\begin{array}{l}\text { C. R. for } \\
\text { differences } \\
\text { between } \\
\text { parameters }\end{array}$} \\
\hline & & & \multicolumn{4}{|c|}{ Coefficients } & \multicolumn{4}{|c|}{ Coefficients } & \\
\hline & & & Std. & Unstd. & C.R. & $\mathrm{P}$ & Std. & Unstd. & C.R. & $\mathrm{P}$ & \\
\hline Banrisul & H4 & $\mathrm{OBE}<-\mathrm{OTID}$ & .079 & .089 & 2.666 & .008 & .210 & .205 & 6.145 & $* * *$ & $2.465^{\mathrm{a}}$ \\
\hline Unimed & $\mathrm{H} 4$ & $\mathrm{OBE}<-\mathrm{OTID}$ & .077 & .078 & 2.052 & .040 & .147 & .142 & 5.327 & $* * *$ & $1.395^{b}$ \\
\hline
\end{tabular}

Note. ${ }^{a}$ Moderation effect supported; ${ }^{\mathrm{b}}$ Moderation effect not supported. $* * * \mathrm{p}<.01$

Finally, in order to verify the mediation effect of team-sponsor fit, a mediation test was conducted using Baron and Kenny's (1986) causal steps approach. We verified that (a) there is an effect that may be mediated, i.e. there is a significant relation between team identification (causal variable) and the sponsor's brand equity (outcome); (b) there is a significant relationship between team identification (causal variable) and team-sponsor fit (mediator); (c) the mediator affects the outcome when the causal variable is controlled, i.e. team-sponsor fit is significantly related to the sponsor's brand equity when both team identification and team-sponsor fit are included as predictors of the dependent variable; and (d) since the effect of team identification (causal variable) on sponsor's brand equity (outcome) is not reduced to zero, the mediation effect is partial (See Table 8). Then, in order to evaluate the significance of the mediation effect, the Sobel test was conducted. Results indicate that team-sponsor fit partially mediates the relationship between team identification and the sponsor's brand equity for both Banrisul $(\mathrm{z}=7.215)$ and Unimed $(\mathrm{z}=8.028)$.

Table 8

Results of the Mediation Tests

\begin{tabular}{|c|c|c|c|c|c|c|}
\hline Sponsor & Steps & Variable & $\begin{array}{c}\text { Unstd. } \\
\text { Coefficient }\end{array}$ & S.E. & $\mathrm{P}$-value & Sobel test (z) \\
\hline \multirow[t]{10}{*}{ Banrisul } & Step 1 & & & & & \multirow{10}{*}{$7.215 * * *$} \\
\hline & Outcome & $\mathrm{OBE}$ & - & - & - & \\
\hline & Predictor & OTID & .300 & .035 & $* * *$ & \\
\hline & Step 2 & & & & & \\
\hline & Outcome & FIT & - & - & - & \\
\hline & Predictor & OTID & .242 & .031 & $* * *$ & \\
\hline & Steps 3 and 4 & & & & & \\
\hline & Outcome & OBE & - & - & - & \\
\hline & Mediator & FIT & .718 & .038 & $* * *$ & \\
\hline & Predictor & OTID & .145 & .025 & $* * *$ & \\
\hline
\end{tabular}

Continues 
Table 8 (continued)

\begin{tabular}{|c|c|c|c|c|c|c|}
\hline Sponsor & Steps & Variable & $\begin{array}{c}\text { Unstd. } \\
\text { Coefficient }\end{array}$ & S.E. & P-value & Sobel test (z) \\
\hline \multirow[t]{10}{*}{ Unimed } & Step 1 & & & & & \multirow{10}{*}{$8.028 * * *$} \\
\hline & Outcome & OBE & - & - & - & \\
\hline & Predictor & OTID & .317 & .034 & $* * *$ & \\
\hline & Step 2 & & & & & \\
\hline & Outcome & FIT & - & - & - & \\
\hline & Predictor & OTID & .267 & .030 & $* * *$ & \\
\hline & Steps 3 and 4 & & & & & \\
\hline & Outcome & OBE & - & - & - & \\
\hline & Mediator & FIT & .651 & .035 & $* * *$ & \\
\hline & Predictor & OTID & .131 & .023 & $* * *$ & \\
\hline
\end{tabular}

Note. $* * *$ Significant at the .001 level.

\section{Discussion and Contributions}

\section{Theoretical implications}

\section{Simultaneous sponsorship of rival teams: a trade off}

There is substantial evidence in the literature that fans with high levels of identification tend to show more positive reactions regarding the sponsors (Gwinner \& Swanson, 2003; Sutton et al., 1997; Wang et al., 2011). The resultants of team identification include brand recognition, satisfaction with the sponsors, support for the sponsors (Gwinner \& Swanson, 2003), more frequent watching of game broadcasts, greater volume of purchases of team-related products (Carlson, Donavan, \& Cumiskey, 2009) and a greater chance of purchasing the sponsor's products (Madrigal, 1995).

However, the results of the present study are not aligned with the literature's findings. Although the analyses performed of Banrisul and Unimed revealed a statistically significant influence of team identification on sponsors' brand equity and team-sponsor fit, team identification showed no relevant direct effect on either of the constructs, suggesting that in the context of simultaneous sponsorship of rivals, team identification plays a different role on fans' perceptions.

In a non-shared context of sport sponsorship, studies show that highly identified fans tend to demonstrate negative reactions regarding the sponsor of their team's rival, resulting in a negative effect in their purchase intentions of products of the sponsoring brand (Torres \& Andrade, 2012). According to Davies, Veloutsou and Costa (2006), by sponsoring two local rival teams, the sponsor affects fans differently, given that fans who are more involved with each team tend to develop a resistance to the sponsor because they are against sharing it with their rival.

According to the Social Identity Theory perspective, the sponsor of the fan's team is perceived as a new member of the group, enjoying the positive consequences of this status, given that providing support for this new member of the group constitutes natural behavior on the part of the sponsored team's fans (Fischer \& Wakefield, 1998). However, by sponsoring the rival team, it is possible that the sponsor will be regarded with suspicion by the fans. The sponsor may no longer be perceived as a 
genuine member of the group, therefore will no longer enjoy these benefits in the same way as if it would sponsor only one of the teams.

\section{The importance of fit}

It is known that sponsor-sponsored entity fit, whether a sports event or a team, can have a positive impact on consumers' attitudes towards the sponsor (Dees, Bennett, \& Ferreira, 2010; Deitz et al., 2012; Rifon, Choi, Trimble, \& Li, 2004; Roy \& Cornwell, 2003; Speed \& Thompson, 2000), it's level of brand recognition (Koo et al., 2006), brand recall (Johar \& Pham, 1999), brand attractiveness (Woisetschläger et al., 2010) and brand equity (Wang et al., 2011).

However, specifically in the context of simultaneous sponsorship of rival teams, a previous study shows that the sponsorship of rival teams affects fans' perceptions in different ways. Two effects occur simultaneously: whereas the fans who identify the most with each team tend to develop a resistance to the sponsor, because they are not willing to share the sponsor with their rival, the effects of the perceived team-sponsor fit have a positive impact on attitudes towards the sponsor, partially offsetting the resistance created by the joint sponsorship (Davies et al., 2006).

The results of the present study provide additional empirical evidence that, in the context of simultaneous sponsorship of rival teams, there may be a displacement of the importance of team identification to the team-sponsor fit, where positive effects remains. In other words, team-sponsor fit should not be neglected in order to avoid the risk of destroying sponsor brand-equity.

\section{The importance of customer experience}

The study confirmed the negative moderating effect of previous experience with the sponsor on the relationship between team identification and brand equity. Considering that brand equity is formed by all direct and indirect contacts that customers have with firms (Villarejo-Ramos \& Sánchez-Franco, 2005), we verified that this experience has a significant influence on fans' perceptions, modifying the effects of sports sponsorship on sponsors' brand equity, given that personal experience is one of the most powerful source of references regarding any firm (Berry, 2000). In other words, if the level of team identification acts as a positive bias in the assessment of sponsors' brand equities, fans' experience with these firms could attenuate or even nullify this bias, making the sponsor brand equity formation process more personal and rational, and thus less influenced by external factors such as, for example, advertising and sports sponsorship.

\section{Managerial implications}

As the research verified, the simultaneous sponsorship of rival teams can lead to positive and negative results for the sponsoring firm. One could suppose that in a context of fierce rivalry and local polarization between two groups of fans, as is the case in Porto Alegre, sponsoring both clubs may be seen as a defensive action that aims to reduce potential hostility on the part of distinct groups of fans by adopting a neutral stance. However, this strategy can also be perceived by fans as reflecting a conservative or even cowardly attitude, given that the sponsor does not adopt a clear position. Therefore, the sponsor thus foregoes an important part of these benefits, choosing to reach both groups of fans only partially, instead of achieving all the effects of the sponsorship with one of the groups of fans.

In other words, the team-sponsor relation is unfortunately reduced to a quid pro quo so common in the Brazilian sponsorship scene: funds from a sponsor in exchange for the visibility provided by the media. Naturally, the sponsorship of football (soccer) teams, due to the widespread popularity of this sport in Brazil, constitutes an important marketing communication and brand promotion tool. However, due to the large audiences reached by this kind of sponsorship, many firms are only concerned with the visibility of their sponsorship relations, establishing their objectives according to 
the number of spectators reached. However, as the results of this study suggest, visibility is only one of the possible effects of sports sponsorship.

\section{Limitations and Suggestions for Future Studies}

The present study has some limitations. In the first place, despite all the care taken in reverse translation, the formulation of scale items does not ensure a perfect fit, especially due to the cultural issue. Despite the good results of the fit scale, the term is not widely used in the country. Second, despite the adequate size of the sample, there are limitations in using a non-probabilistic sample. Third, this model does not include all the variables that affect sponsor brand equity in the context of sports sponsorship. Thus, if used in the study, these exogenous variables could interact with the variables used, interfering in the relations proposed in the model. Lastly, another limitation concerns the fact that the dependent and independent variables were informed by the same respondent, so common method bias may have influenced some of the results, however, the EFA did not present evidences of the occurrence of this effect.

The theoretical framework proposed in this study can be tested and validated in other sports and other contexts involving rivalries between teams from the same city. Other studies could also test the possible moderating effect of other socio-demographic variables, as well as include other antecedents of sponsor brand-equity and, specially, team-sponsor fit in the theoretical framework.

\section{Acknowledgements}

The authors would like to thank FAPERJ - Fundação de Amparo à Pesquisa do Estado do Rio de Janeiro (103.315/2011) - for its support of this research.

\section{References}

Aaker, D. A. (1991). Managing brand equity. Nova York: The Free Press.

Aaker, D. A. (1996). Measuring brand equity across products and markets. California Management Review, 38(3), 102-120. doi: 10.2307/41165845

Anderson, J. (1983). A spreading activation theory of memory. Journal of Verbal Learning and Verbal Behavior, 22(3), 261-295. doi: 10.1016/S0022-5371(83)90201-3

Arshad, S. (2014, July 27). Most expensive kit sponsorship deals in football. Retrieved from http://www.tsmplug.com/top-10/most-expensive-kit-sponsorship-deals-in-football/

Ashfort, B., \& Mael, F. (1989). Social identity theory and the organization. Academy of Management Review, 14(1), 20-39. doi: 10.2307/258189

Axelrod, R. (1973). Schema theory: an information processing model of perception and cognition. The American Political Science Review, 67(4), 1248-1266. doi: 10.2307/1956546

$\begin{gathered}\text { Banrisul. } \\ \text { http://www.banrisul.com.br/bob/link/bobw00hn_historia.aspx?secao_id=23 }\end{gathered}$ (nidória.
Retrieved 
Baron, R., \& Kenny, D. (1986). The moderator-mediator variable distinction in social psychological research: conceptual, strategic, and statistical considerations. Journal of Personality and Social Psychology, 51(6), 1173-1182. doi: http://dx.doi.org/10.1037/0022-3514.51.6.1173

Bennett, G., Ferreira, M., Lee, J., \& Polite, F. (2009). The role of involvement in sports and sport spectatorship in sponsor's brand use: the case of mountain dew and action sports sponsorship. Sport Marketing Quarterly, 18(1), 14-24.

Berry, L. (2000). Cultivating service brand equity. Journal of the Academy of Marketing Science, 28(1), 128-137. doi: 10.1177/0092070300281012

Braunstein-Minkove, J., Zhang, J., \& Trail, G. (2011). Athlete endorser effectiveness: model development and analysis. Sport, Business and Management: an International Journal, 1(1), 93-114. doi: 10.1108/20426781111107199

Capelo, R. (2011, Junho 7). Inter e Grêmio negociam renovação com Banrisul. Retrieved from http://maquinadoesporte.uol.com.br/artigo/inter-e-gremio-negociam-renovacao-combanrisul_15144.html

Carlson, B., Donavan, T., \& Cumiskey, K. (2009). Consumer-brand relationships in sport: brand personality and identification. International Journal of Retail \& Distribution Management, 37(4), 370-384. doi: 10.1108/09590550910948592

Christodoulides, G., \& Chernatony, L. de (2010). Consumer-based brand equity conceptualisation and measurement. International Journal of Market Research, 52(1), 43-66. doi: $10.2501 / \mathrm{S} 1470785310201053$

Christodoulides, G., Chernatony, L. de, Furrer, O., Shiu, E., \& Abimbola, T. (2006). Conceptualising and measuring the equity of online brands. Journal of Marketing Management, 22(7-8), 799825. doi: 10.1362/026725706778612149

Collins, A., \& Loftus, E. (1975). A spreading-activation theory of semantic process. Psychological Review, 82(6), 407-428. doi: 10.1037/0033-295X.82.6.407

Cornwell, T. B. (2008). State of art and science in sponsorship-linked marketing. Journal of Advertising, 37(3), 41-55. doi: 10.2753/JOA0091-3367370304

Cornwell, T. B., Humphreys, M. S., Maguire, A. M., Weeks, C. S., \& Tellegen, C. L. (2006). Sponsorship-linked marketing: the role of articulation in memory. Journal of Consumer Research, 33(3), 312-321. doi: 10.1086/508436

Cornwell, T. B., \& Maignan, I. (1998). An international review of sport sponsorship research. Journal of Advertising, 27(1), 1-21. doi: 10.1080/00913367.1998.10673539

Costa, L. S., \& Almeida, V. M. (2012). Valor da marca: teste empírico da importância das dimensões formadoras do valor da marca na perspectiva do consumidor no contexto brasileiro. Revista Brasileira de Marketing, 11(2), 43-68. doi: 10.5585/remark.v11i2.2357

Davies, F., Veloutsou, C., \& Costa, A. (2006). Investigating the influence of a joint sponsorship of rival teams on supporters attitudes and brand preferences. Journal of Marketing Communications, 12(1), 31-48. doi: 10.1080/13527260500264574

Dees, W., Bennett, G., \& Ferreira, M. (2010). Personality fit in NASCAR: an evaluation of driversponsor congruence and its impact on sponsorship effectiveness outcomes. Sport Marketing Quarterly, 19(1), 25-35. 
Deitz, G., Myers, S., \& Stafford, M. (2012). Understanding consumer response to sponsorship information: a resource-matching approach. Psychology and Marketing, 29(4), 226-239. doi: 10.1002/mar.20517

Drengner, J., Jahn, S., \& Zanger, C. (2011). Measuring event-brand congruence. Event Management, 15(1), 25-36. doi: 10.3727/152599511X12990855575060

Fischer, R., \& Wakefield, K. (1998). Factors leading to group identification: a field study of winners and losers. Psychology \& Marketing, 15(1), 23-40. doi: 10.1002/(SICI)15206793(199801)15:1\%3C23::AID-MAR3\%3E3.3.CO;2-W

Fornell, C., \& Larcker, D. (1981). Evaluating structural equation models with unobservable variables and measurement error. Journal of Marketing Research, 18(1), 39-50. doi: 10.2307/3151312

Frazier, P., Barron, K., \& Tix, A. (2004). Testing moderator and mediator effects in counseling psychology research. Journal of Counseling Psychology, 51(1), 115-134. doi: 10.1037/00220167.51.1.115

Giacomini, G., \& Almeida, V. M. (2013, setembro). A influência da identificação do fã de esportes no consumo de eventos esportivos. Anais do Encontro Nacional da Associação Nacional de PósGraduação e Pesquisa em Administração, Rio de Janeiro, RJ, Brasil, 37.

Gwinner, K., \& Bennett, G. (2008). The impact of brand cohesiveness and sport identification on brand fit in a sponsorship context. Journal of Sport Management, 22(4), 410-426.

Gwinner, K., \& Eaton, J. (1999). Building brand image through event sponsorship: the role of image transfer. Journal of Advertising, 28(4), 47-57. doi: 10.1080/00913367.1999.10673595

Gwinner, K., \& Swanson, S. (2003). A model of fan identification: antecedents and sponsorship outcomes. Journal of Services Marketing, 17(3), 275-294. doi: 10.1108/08876040310474828

Gwinner, K., Larson, B., \& Swanson, S. (2009). Image transfer in corporate event sponsorship: assessing the impact of team identification and event-sponsor fit. International Journal of Management and Marketing Research, 2(1), 1-15.

Hair, J. F., Black, W. C., Babin, B. J., Anderson, R. E., \& Tatham, R. L. (2006). Multivariate data analysis (6th ed., pp. 101-166). Upper Saddle River, NJ: Pearson Prentice Hall.

Holbert, L., \& Stephenson, M. (2003). The importance of indirect effects in media effects research: Testing for mediation in structural equation modeling. Journal of Broadcasting \& Electronic Media, 47(4), 556-572. doi: 10.1207/s15506878jobem4704_5

Johar, G., \& Pham, M. (1999). Relatedness, prominence, and constructive sponsor identification. Journal of Marketing Research, 36(3), 299-312. doi: 10.2307/3152078

Jung, J., \& Sung, E. (2008). Consumer-based brand equity: comparisons among Americans and South Koreans in the USA and South Koreans in Korea. Journal of Fashion Marketing and Management, 12(1), 24-35. doi: 10.1108/13612020810857925

Keller, K. L. (1993). Conceptualizing, measuring, and managing customer-based brand equity. Journal of Marketing, 57(1), 1-22. doi: 10.2307/1252054

Kline, R. (2005). Principles and practice of structural equation modeling. New York: The Guilford Press.

Koo, G.-Y., Quarterman, J., \& Flynn, L. (2006). Effect of perceived sport event and sponsor image fit on consumer's congnition, affect, and behavioral intentions. Sport Marketing Quarterly, 15(2), 80-90. 
Lordello, V. (2013, Agosto 23). Patrocínio esportivo no Brasil já atinge R\$3 bi/ano. Retrieved from http://exame.abril.com.br/rede-de-blogs/esporte-executivo/2013/08/23/patrocinio-esportivo-nobrasil-ja-atinge-r-3-biano/

Madrigal, R. (1995). Cognitive and affective determinants of team satisfaction with sporting event attendance. Journal of Leisure Research, 27(3), 205-277.

PwC. (2011). Changing the game: outlook for the global sports market to 2015. Retrieved from http://www.pwc.com/en_GX/gx/hospitality-leisure/pdf/changing-the-game-outlook-for-theglobal-sports-market-to-2015.pdf

Rifon, N., Choi, S., Trimble, C., \& Li, H. (2004). Congruence effects in sponsorship: the mediating role of sponsor credibility and consumer attributions of sponsor motive. Journal of Advertising, 33(1), 29-42. doi: 10.1080/00913367.2004.10639151

Rines, S. (2000). Driving business through sport: analysis of Europe's sponsorship industry, business opportunities and best practice. London: International Marketing Reports Ltd.

Ross, S. (2006). A conceptual framework for understanding spectator-based brand equity. Journal of Sport Management, 20(1), 22-38.

Roy, D., \& Cornwell, B. (2003). Brand equity's influence on responses to event sponsorship. Journal of Product \& Brand Management, 12(6), 377-393. doi: 10.1108/10610420310498803

Singer, J. (1968). Consistency as a stimulus process mechanism. In R. Abelson, E. Aronson, W. Rosenberg, \& P. Tannenbaum, Theories of cognitive consistency: a sourcebook (pp. 337-342). Chicago: Rand-McNally.

Sobel, M. (1982). Asymptotic confidence intervals for indirect effects in structural equation models. Sociological Methodology, 13(1), 290-312. doi: 10.2307/270723

Somoggi, A. (2014). Finanças dos clubes brasileiros em 2013. São Paulo: Marketing e Gestão Esportiva.

Speed, R., \& Thompson, P. (2000). Determinants of sports sponsorship response. Journal of the Academy of Marketing Science, 28(2), 226-238. doi: 10.1177/0092070300282004

Srivastava, R. K., \& Shocker, A. (1991). Brand equity: a perspective on its meaning and measurement [Working paper]. Marketing Science Institute, Boston, MA, 91-124.

Sutton, W., McDonald, M., Milne, G., \& Cimperman, J. (1997). Creating and fostering fan identification in professional sports. Sport Marketing Quarterly, 6(1), 15-22.

Tajfel, H. (1982). Social psychology of intergroup relations. Annual Review of Psychology, 33(1), 139. doi: 10.1146/annurev.ps.33.020182.000245

Tajfel, H., \& Turner, J. (1979). An integrative theory of intergroup conflict. In W. Austin, \& S. Worchel, The social psychology of intergroup relations (pp. 33-47). Monterrey, CA: Brooks/Cole.

Torres, A. C., \& Andrade, J. (2012, maio). Atitudes de torcedores de futebol frente a marcas patrocinadoras de times rivais ao seu. Um estudo exploratório. Anais do Encontro da Divisão de Marketing da Associação Nacional de Pós-Graduação e Pesquisa em Administração, Curitiba, PR, Brasil, 5.

Trail, G., Robinson, M., Dick, R., \& Gillentine, A. (2003). Motives and points of attachment: fans versus spectators in intercollegiate athletics. Sport Marketing Quarterly, 12(4), 217-227. 
Turco, L. (2013, Fevereiro 15). Grêmio tem negociações avançadas com Unimed. Retrieved from http://maquinadoesporte.uol.com.br/artigo/gremio-tem-negociacoes-avancadas-comunimed_22631.html

Unimed do Brasil. (2013, Maio 5). Sobre a Unimed do Brasil. Retrieved from http://www.unimed.coop.br/pct/index.jsp?cd_canal=49146\&cd_secao=49112

Villarejo-Ramos, A., \& Sánchez-Franco, M. (2005). The impact of marketing communication and price promotion on brand equity. Brand Management, 12(6), 431-444. doi: 10.1057/palgrave.bm.2540238

Walliser, B. (2003). An international review of sponsorship research: extension and update. International Journal of Advertising, 22(1), 5-44. doi: 10.1080/02650487.2003.11072838

Wang, M. C.-H., Cheng, J. M.-S., Purwanto, B., \& Erimurti, K. (2011). The determinants of the sports team sponsor's brand equity: a cross-country comparison in Asia. International Journal of Market Research, 53(6), 811-829. doi: 10.2501/IJMR-53-6-811-829

Wann, D. L. (2002). Preliminary validation of a measure for assessing identification as a sport fan: the sport fandom questionnaire. International Journal of Sport Management, 3(1), 103-115.

Wann, D. L., \& Branscombe, N. (1993). Sports fans: measuring the degree of identification with their team. International Journal of Sport Psychology, 24(1), 1-17.

Woisetschläger, D., Eiting, A., Haselhoff, V., \& Michaelis, M. (2010). Determinants and consequences of sponsorship fit: a study of fan perceptions. Journal of Sponsorship, 3(2), 169-180.

Yoo, B., \& Donthu, N. (2001). Developing and validating a multidimensional consumer-based brand equity scale. Journal of Business Research, 52(1), 1-14. doi: 10.1016/S0148-2963(99)00098-3

\section{Authors' Profiles}

João Guilherme Barbosa de Amorim

Rua Pascoal Lemme, 355, Ilha do Fundão, 21941-918, Rio de Janeiro, RJ, Brazil. E-mail address: jgbamorim@yahoo.com.br

Victor Manoel Cunha de Almeida

Rua Pascoal Lemme, 355, Ilha do Fundão, 21941-918, Rio de Janeiro, RJ, Brazil. E-mail address: valmeida@ coppead.ufrj.br 


\section{APPENDIX}

\section{Translated Version of the Scales}

\begin{tabular}{|c|c|c|}
\hline Scale & Item & Item Formulation \\
\hline \multirow{3}{*}{$\begin{array}{l}\text { Team Identification } \\
\text { (otid) }\end{array}$} & otid_1 & Eu me considero um(a) Gremista/Colorado de verdade. \\
\hline & otid_2 & Eu me sentiria perdido(a) se tivesse que deixar de ser torcedor do (Time). \\
\hline & otid_3 & Ser um(a) torcedor(a) do (Time) é muito importante para mim. \\
\hline \multirow{5}{*}{$\begin{array}{l}\text { Banrisul-Team Fit } \\
\text { (fit_b) }\end{array}$} & fit_b1 & Há uma ligação entre o (Time) e o Banrisul. \\
\hline & fit_b2 & A imagem do (Time) e a imagem do Banrisul são compatíveis. \\
\hline & fit_b3 & O Banrisul e o (Time) combinam bem juntos. \\
\hline & fit_b4 & O Banrisul e o (Time) têm muito em comum. \\
\hline & fit_b5 & Para mim, faz sentido que o Banrisul patrocine o (Time). \\
\hline \multirow{5}{*}{$\begin{array}{l}\text { Unimed-Team Fit } \\
\text { (fit_u) }\end{array}$} & fit_u1 & Há uma ligação entre o (Time) e a Unimed. \\
\hline & fit_u2 & A imagem do (Time) e a imagem da Unimed são compatíveis. \\
\hline & fit_u3 & O (Time) e a Unimed combinam bem juntos. \\
\hline & fit_u4 & O (Time) e a Unimed têm muito em comum. \\
\hline & fit_u5 & Para mim, faz sentido que a Unimed patrocine o (Time). \\
\hline \multirow{4}{*}{$\begin{array}{l}\text { Banrisul Overall } \\
\text { Brand Equity } \\
\text { (obe_b) }\end{array}$} & obe_b1 & $\begin{array}{l}\text { Vale a pena usar o Banrisul, mesmo que os serviços sejam iguais aos de } \\
\text { outros bancos. }\end{array}$ \\
\hline & obe_b2 & $\begin{array}{l}\text { Ainda que outros bancos ofereçam os mesmos serviços, eu prefiro o } \\
\text { Banrisul. }\end{array}$ \\
\hline & obe_b3 & $\begin{array}{l}\text { Mesmo que haja outro banco tão bom quanto, eu ainda prefiro usar os } \\
\text { serviços do Banrisul. }\end{array}$ \\
\hline & obe_b4 & $\begin{array}{l}\text { Se outros bancos não apresentam diferenças nos serviços, parece mais } \\
\text { inteligente escolher o Banrisul. }\end{array}$ \\
\hline \multirow{4}{*}{$\begin{array}{l}\text { Unimed Overall } \\
\text { Brand Equity } \\
\text { (obe_u) }\end{array}$} & obe_u1 & $\begin{array}{l}\text { Vale a pena ter o plano de saúde da Unimed, mesmo que os benefícios } \\
\text { sejam iguais aos de outros planos de saúde. }\end{array}$ \\
\hline & obe_u2 & $\begin{array}{l}\text { Ainda que outros planos de saúde ofereçam os mesmos benefícios, eu } \\
\text { prefiro a Unimed. }\end{array}$ \\
\hline & obe_u3 & $\begin{array}{l}\text { Mesmo que haja outro plano de saúde tão bom quanto, eu ainda prefiro ter } \\
\text { o plano de saúde da Unimed. }\end{array}$ \\
\hline & obe_u4 & $\begin{array}{l}\text { Se outros planos de saúde não apresentam diferenças nos benefícios, parece } \\
\text { mais inteligente escolher o plano de saúde da Unimed. }\end{array}$ \\
\hline
\end{tabular}

